\title{
New sweet blue lupin, Lupinus angustifolius L. varieties (Sanabor and Vitabor) for Ethiopia
}

\author{
Likawent Yeheyis ${ }^{1, *}$ and Wondimeneh Mekonnen ${ }^{2}$ \\ ${ }^{1}$ Amhara Agricultural Research Institute, Bahir Dar, Ethiopia \\ ${ }^{2}$ Andassa Livestock Research Centre, Bahir Dar, Ethiopia
}

\begin{abstract}
Though bitter white lupin is an ancient pulse crop to Ethiopia, sweet lupins are new to the country. Sanabor and Vitabor are recently introduced sweet blue lupin varieties to be used as multipurpose crop in the traditional lupin growing agro-ecologies of Ethiopia. These varieties were introduced from Germany and evaluated along with fourteen other varieties which have been tested in different locations of the country from 2009 to 2013. The varieties are registered at national level in 2014. The merits of the varieties are their low alkaloid content, high seed yield, resistance to anthracnose and fusarium, most importantly are palatable for livestock and can be used for human food. Thus, the varieties are recommended as multipurpose pulse crop for the traditional and new lupin growing areas.
\end{abstract}

Keywords:- Alkaloids; Blue Lupin; Sanabor; Sweet Lupin; Vitabor

DOI: https://dx.doi.org/10.4314/ejst.v15i1.5

\section{INTRODUCTION}

Wild lupines are believed to be originated and are concentrated in two large areas: The old world or the Mediterranean region and the new world or the Americas. Because of the diverse species, the genus Lupinus is found widely distributed in different parts of the world in several agro climatic conditions, from the sub-arctic climate, through the Mediterranean and semi-desert climates, to the highlands of East Africa, Mexico, and finally the sub-tropical lowlands of eastern South America and south-eastern USA. Among the four large seeded annual lupin species, three of the species, i.e., white lupin, blue lupin and yellow lupin, have originated in the Mediterranean basin (Kurlovich, 2002). White Lupin is one of the common pulse crops grown in Ethiopia (Likawent Yeheyis et al., 2010). It is an

\footnotetext{
*Corresponding Author: likawenty@yahoo.com

(C) This is an Open Access article distributed under the terms of the Creative Commons Attribution License (http://creativecommons.org/licenses/CC BY4.0)
} 
ancient traditional multipurpose crop being cultivated particularly in Northwestern Ethiopia. In Ethiopia, white lupin is believed to have originated and introduced into Ethiopia from Egypt. It is also believed that the Amharic local name of lupin in Ethiopia, Gibto, has been derived from the Amharic name of Egypt, Gibtsi. It is produced by small holder farmers in two regional states of Ethiopia, Amhara and Benishangul Gumuz, the former being the largest producer. In this region of the country, the total crop land covered by lupin ranges between 7, 000 to 19,900 ha per year (ECSA, 2017). The crop is known as a very easy crop to grow with a relatively high yield and minimal agronomic practices. It grows from the warm mid-altitude areas of South Gondar up to the cool and humid highaltitude areas of West Gojam. The major soil types in these areas are Nitosols and Acrisols. The ability of the crop to be grown in acidic soils is one of the major important features of the crop in the traditional lupin growing areas of Ethiopia (Likawent Yeheyis et al., 2010). However, this traditional pulse crop has low food value and is unpalatable to livestock due to its high alkaloid content (Likawent Yeheyis et al., 2011a). Though there are sweet lupin species with very low alkaloid content (around $200 \mathrm{mg} / \mathrm{kg}$ dry matter) which are suitable for both human food and livestock feed, they were not introduced to Ethiopia.

Therefore, to answer this question, a series of experiments were conducted around West Gojam and Awi Administrative Zones. The experiments were adaptation trials using 14 sweet lupin varieties (Likawent Yeheyis et al., 2012b), an extensive laboratory evaluation of these varieties (Likawent Yeheyis et al., 2012a) and a feeding trial on sheep using lupin seed as protein source (Likawent Yeheyis et al., 2012c). The results of the experiments showed that about four sweet blue lupin varieties (Sanabor, Vitabor, Bora and Probor) were found to be adaptive and promising to be used as livestock feed and other purposes in the study area and other similar agro-ecologies. But for wider dissemination and utilization of these varieties by farmers the varieties have to be officially registered by Ministry of Agriculture (MOA). Hence, a verification trial was conducted to verify the results obtained in the previous experiments and were officially registered as promising varieties by the MOA. After the verification trial, two multipurpose sweet blue lupin (Lupinus angustifolius L.) varieties namely Sanabor and Vitabor, were released for the traditional lupin growing areas of Ethiopia in 2014 (Table 1). These varieties currently are being introduced to the three districts of West Gojam area (South Achefer, Bure and Jabitehnan) as feed and food pulse crop. In south Achefer district, the varieties are being utilized by local farmers for the preparation of a traditional stew known as Shiro and Kikwot. 
Table 1. Description of the released blue sweet lupin varieties, Sanabor and Vitabor.

\begin{tabular}{|c|c|c|}
\hline \multirow{2}{*}{$\begin{array}{l}\text { Agronomic and } \\
\text { morphological } \\
\text { characteristics }\end{array}$} & \multicolumn{2}{|c|}{ Varieties } \\
\hline & Sanabor & Vitabor \\
\hline Adaptation area & $\begin{array}{l}\text { Traditional lupin growing } \\
\text { areas of West Gojam, Awi and } \\
\text { South Gondar Zones }\end{array}$ & $\begin{array}{l}\text { Traditional lupin growing } \\
\text { areas of West Gojam, Awi and } \\
\text { South Gondar Zones }\end{array}$ \\
\hline Altitude (m.a.s.1.) & $1935-2610$ & $1935-2610$ \\
\hline Rainfall (mm) & $1189-2348$ & $1189-2348$ \\
\hline $\begin{array}{l}\text { Seed rate when } \\
\text { broadcasted }(\mathrm{Kg} / \mathrm{ha})\end{array}$ & 80 for broadcasting & 80 for broadcasting \\
\hline Spacing for row planting & $\begin{array}{l}30 \mathrm{~cm} \text { between rows and } 6-7 \\
\mathrm{~cm} \text { between plants }\end{array}$ & $\begin{array}{l}30 \mathrm{~cm} \text { between rows and } 6-7 \\
\mathrm{~cm} \text { between plants }\end{array}$ \\
\hline Planting date & First week of July & First week of July \\
\hline Fertilizer rate $(\mathrm{Kg} / \mathrm{ha})$ & $\begin{array}{l}100 \text { DAP and } 50 \text { Urea at } \\
\text { planting. It is also possible to } \\
\text { plant it without fertilizer }\end{array}$ & $\begin{array}{l}100 \text { DAP and } 50 \text { Urea at } \\
\text { planting. It is also possible to } \\
\text { plant it without fertilizer }\end{array}$ \\
\hline Days to flowering & 60 (days to $50 \%$ flowering) & 66 (days to $50 \%$ flowering) \\
\hline Days to maturity & 140 & 141 \\
\hline Plant height $(\mathrm{cm})$ & 90 & 78 \\
\hline Growth habit & Indeterminate & Indeterminate \\
\hline Flower color & $\begin{array}{l}\text { A mix of white and blue, white } \\
\text { is dominant }\end{array}$ & $\begin{array}{l}\text { A mix of blue and white, blue } \\
\text { is dominant }\end{array}$ \\
\hline Thousand seed weight (g) & 160 & 138 \\
\hline Seed color & Grey (Cream) & Grey (Cream) \\
\hline Crop pest reaction & $\begin{array}{l}\text { Tolerant to fusarium and } \\
\text { anthracnose }\end{array}$ & $\begin{array}{l}\text { Tolerant to fusarium and } \\
\text { anthracnose }\end{array}$ \\
\hline Crude protein content $(\%)$ & 35 & 32 \\
\hline $\begin{array}{l}\text { Seed Alkaloid content } \\
(\%)\end{array}$ & $0.018-0.052$ & $0.023-0.050$ \\
\hline $\begin{array}{l}\text { Forage Alkaloid content } \\
(\%)\end{array}$ & $0.042-0.082$ & $0.011-0.046$ \\
\hline $\begin{array}{l}\text { Grain yield (qt/ha) on } \\
\text { researcher field }\end{array}$ & 37 & 38 \\
\hline $\begin{array}{l}\text { Grain yield (qt/ha) on } \\
\text { farmer field }\end{array}$ & 31 & 28 \\
\hline Year of release & 2014 & 2014 \\
\hline Breeder seed maintainer & ARARI and Andassa & ARARI and Andassa \\
\hline
\end{tabular}




\section{MATERIALS AND METHODS}

\section{Origin of seeds and evaluation method of the varieties}

The varieties were developed using an adaptation trial in four locations (Merawi $\left(11.27^{\circ} \mathrm{N} 37.56^{\circ} \mathrm{E}\right)$, Finote Selam $\left(10.84^{\circ} \mathrm{N} 37.36^{\circ} \mathrm{E}\right)$, Kossober- 1 and $2\left(10.85^{\circ} \mathrm{N}\right.$ $36.80^{\circ} \mathrm{E}$ ) in north-western Ethiopia). A total of sixteen annual lupin varieties of three species were used, fifteen of them were introduced from Germany and USA in 2009. The varieties used were white lupin varieties (Local Landrace, Fortuna, Feodora, L-1082, L-1057, AU-Alpha, AU-Homer), blue lupin varieties (Bora, Boregine, Borlu, Boruta, Haags Blaue, Probor, Sanabor, Vitabor) and yellow lupin cultivar (Bornal). Except the white Local Landrace and AU-Homer, the remaining 14 varieties were sweet varieties. The white Local Landrace was included as a local check and the seed was purchased from local markets of the respective testing sites. Fortuna and Feodora seeds were obtained from Südwestdeutsche Saatzucht, Germany. The seed source for L-1082, L-1057, AU-Alpha, AU-Homer was Auburn University, Alabama, USA. For all blue lupin varieties and yellow Bornal the seed source was Saatzucht Steinach GmbH, Germany. For forage and seed sampling, each plot was divided in half crosswise to give an effective plot size of $1.2 \times 2 \mathrm{~m}$. One half of each plot was used for forage sampling and the other half for seed sampling. Forage samples were taken when plants were at around $50 \%$ flowering and seed samples at maturity. In both cases, sampling was conducted from the middle two rows excluding the border rows. Immediately after sampling, the fresh biomass was weighed to estimate green biomass yield. Forage samples were dried in a forced air oven at $65^{\circ} \mathrm{C}$ to constant weight for $\mathrm{DM}$ determination. Seed samples were air dried to constant weight.

\section{Alkaloid and amino acid analysis}

The alkaloid content of the samples was determined by capillary GLC and GLCMS according to the procedures described by Wink et al. (1995) (Table 2). First the ground samples were homogenized in $0.5 \mathrm{~N} \mathrm{HCl}$ solution. This homogenate solution was adjusted to $\mathrm{pH} 12$ with $6 \mathrm{~N}$ aqueous $\mathrm{NaOH}$ solution.

Then from this solution, the alkaloids were extracted by a solid phase extraction method and analyzed by Gas Chromatography-Mass Spectrometry (GLC-MS). The alkaloid analysis was done at the University of Heidelberg, Germany. Analysis of the amino acid profiles (Table 2) was done according to the procedures described by Naumann and Bassler (1997). 
Table 2. Forage and seed alkaloid contents $(\mathrm{mg} / \mathrm{kg} \mathrm{DM})$ from laboratory evaluation of selected white, blue, and yellow annual lupin accessions at four locations in Ethiopia $(2009 / 10)$.

\begin{tabular}{|c|c|c|c|c|}
\hline \multirow[t]{2}{*}{ Species, Cultivar } & \multicolumn{2}{|c|}{ Mid-altitude } & \multicolumn{2}{|c|}{ High-altitude } \\
\hline & Merawi & Finote Selam & Kosober 1 & Kosober 2 \\
\hline \multicolumn{5}{|c|}{ Seeds } \\
\hline White, Local & 16752 & & & 11426 \\
\hline Blue, Bora & 2261 & & & 983 \\
\hline Blue, Boregine & 1365 & 375 & & 622 \\
\hline Blue, Borlu & 2292 & 750 & & 703 \\
\hline Blue, Boruta & & 653 & 272 & 357 \\
\hline Blue, Haags Blaue & 651 & & 303 & 158 \\
\hline Blue, Probor & & 946 & 365 & 430 \\
\hline Blue, Sanabor & 524 & & & 178 \\
\hline Blue, Vitabor & 452 & 495 & 231 & \\
\hline Blue, Bornal & & & 1642 & \\
\hline White, L-1082 & 769 & 656 & & 481 \\
\hline \multicolumn{5}{|c|}{ Forages } \\
\hline White, Local & & 10231 & & 6153 \\
\hline Blue, Borlu & 267 & & & 607 \\
\hline Blue, Sanabor & 421 & & & 816 \\
\hline Blue, Vitabor & 112 & & 459 & \\
\hline Blue, Bornal & 1306 & & 542 & \\
\hline White, L-1082 & & 328 & & 542 \\
\hline
\end{tabular}

The analyzer used was Biochrom 20 amino acid analyzer. During the analysis, hydrolysis was done by diluted $\mathrm{HCl}$ solution and the quantity of the amino acids in the hydrolysate was determined by ion exchange chromatography using amino acid analyzer (high pressure liquid chromatography). Analysis of the amino acid profiles was done at Technical University of Munich, Germany. The values of all chemical composition parameters are expressed in DM basis. During the field evaluation the alkaloid and amino acid profiles were not analysed for all varieties because of cost implications (Tables 2 and 3 ). 
Table 3. Amino acid profile ( $\mathrm{g} / \mathrm{kg} \mathrm{DM}$ ) of the original (imported) Blue Sanabor seed, and the Ethiopian grown white local and Blue Sanabor (2009/10).

\begin{tabular}{lrrrrr}
\hline Amino Acid & \multicolumn{2}{c}{ Mid altitude } & \multicolumn{2}{c}{ High altitude } & \multicolumn{2}{l}{$\begin{array}{l}\text { Original } \\
\text { Seed } \\
\text { Blue }\end{array}$} \\
\cline { 2 - 6 } \multicolumn{1}{l}{$\begin{array}{l}\text { White } \\
\text { local }\end{array}$} & \multicolumn{1}{l}{$\begin{array}{l}\text { Blue } \\
\text { Sanabor }\end{array}$} & $\begin{array}{l}\text { White } \\
\text { local }\end{array}$ & \multicolumn{1}{l}{$\begin{array}{l}\text { Blue } \\
\text { Sanabor }\end{array}$} & \multicolumn{1}{l}{\begin{tabular}{l} 
Sanabor \\
\hline Cysteine
\end{tabular}} \\
Asparagine & 5.32 & 4.84 & 4.61 & 4.88 & 5.14 \\
Methionine & 34.72 & 32.69 & 35.33 & 31.76 & 33.25 \\
Threonine & 2.03 & 1.95 & 1.94 & 1.84 & 1.91 \\
Serine & 12.41 & 11.35 & 12.46 & 10.76 & 11.43 \\
Glutamine & 17.78 & 16.40 & 18.21 & 15.90 & 16.63 \\
Glycine & 66.05 & 63.08 & 67.31 & 63.25 & 65.74 \\
Alanine & 13.71 & 13.61 & 13.77 & 13.33 & 14.11 \\
Valine & 11.00 & 11.25 & 11.51 & 10.71 & 11.87 \\
Isoleucine & 13.61 & 12.62 & 13.82 & 12.34 & 13.02 \\
Leucine & 15.27 & 14.09 & 15.86 & 13.54 & 14.38 \\
Tyrosine & 24.55 & 22.71 & 24.70 & 22.15 & 23.30 \\
Phenylalanine & 15.69 & 12.67 & 17.69 & 11.81 & 12.63 \\
Histidine & 13.24 & 12.83 & 13.82 & 12.49 & 13.24 \\
Lysine & 8.18 & 9.20 & 8.22 & 9.24 & 9.63 \\
Arginine & 16.16 & 15.82 & 16.43 & 15.59 & 16.68 \\
Proline & 33.37 & 34.37 & 35.33 & 35.64 & 29.87 \\
\hline & 14.65 & 13.25 & 14.97 & 13.12 & 13.78 \\
\hline
\end{tabular}

\section{RESULTS AND DISCUSSION}

\section{Forage yield}

Most white lupin varieties (including the Local Landrace) and yellow cultivar tested had relatively better foliage than the blue varieties. As a result of this the forage yield (Table 4) from most white lupin varieties at the mid-altitude locations and yellow lupin at all locations was relatively good. The lower forage yield from most white lupins at the high-altitude locations could be due to Fusarium wilt and the extended lower temperature during germination and seedling stage as opposed to the lower vernalization requirement of most sweet white lupins. The forage yield of white sweet lupins in this study was comparable with the yield reported by Muyekho (1999) who reported a mean forage yield of $2.5 \mathrm{t} / \mathrm{ha}$ from sweet white lupin cultivar (Ultra) when harvested at three months of age. In addition, the forage yield reported by Bhardwaj et al. (2010) on white lupins in USA ranged between 0.8 and $2 \mathrm{t} / \mathrm{ha}$ which was inline with the observed forage yield performance of most lupin varieties in this study. However, the forage yield observed in this study was lower than the yield reports by Mihailovic et al. (2008) $(8.7 \mathrm{t} / \mathrm{ha})$ from white lupin accessions in Serbia and by Fraser et al. (2005) (8.45 
t/ha) from blue lupin in the UK. This variation in forage yield performance could be due to differences in growing environment and lupin varieties evaluated. Since it is not palatable, the highest biomass yield performance of the Local Landrace at the mid-altitude area shows the potential of the crop as green manure in the mixed crop livestock farming system of the study area. In an experiment conducted to evaluate yellow lupin as a green manure crop preceding winter rye grass in Russia, Takunov and Yagovenko (1999) found that green manuring of yellow lupin increased rye grain yield by 77 and $25 \%$ over the fallow plot and NPK applied plot, respectively.

Table 4. Least square means and contrast estimates for forage yield (t/ha) from an adaptation trial of seven white, eight blue, and one yellow annual lupin accessions at four locations (Merawi, Finoteselam, Kossober-1 and Kossober-2 ) in Ethiopia (2009/10).

\begin{tabular}{|c|c|c|c|c|c|c|}
\hline & \multicolumn{6}{|c|}{ High Altitude } \\
\hline & \multicolumn{3}{|c|}{ Kossober-1 } & \multicolumn{3}{|c|}{ Kossober-2 } \\
\hline & Mean & SE & Rank & Mean & SE & Rank \\
\hline White, Local & 0.2 & 0.34 & 14 & 0.9 & 0.31 & 12 \\
\hline Blue, Bora & 1.7 & 0.28 & 4 & 1.6 & 0.16 & 7 \\
\hline Blue, Boregine & 2.5 & 0.28 & 2 & 2.1 & 0.16 & 4 \\
\hline Blue, Borlu & 1.5 & 0.28 & 5 & 1.6 & 0.16 & 6 \\
\hline Blue, Boruta & 1.5 & 0.28 & 6 & 1.2 & 0.16 & 8 \\
\hline Blue, Haags Blaue & 1 & 0.28 & 10 & 1.1 & 0.16 & 10 \\
\hline Blue, Probor & 1.2 & 0.28 & 9 & 1.1 & 0.16 & 11 \\
\hline Blue, Sanabor & 1.4 & 0.28 & 7 & 1.7 & 0.16 & 5 \\
\hline Blue, Vitabor & 1.7 & 0.28 & 3 & 1.2 & 0.16 & 9 \\
\hline Yellow, Bornal & 2.9 & 0.28 & 1 & 2.3 & 0.53 & 3 \\
\hline White, Feodora & 0 & 0.59 & 16 & 0.3 & 0.31 & 16 \\
\hline White, Fortuna & 0.4 & 0.34 & 13 & 0.6 & 0.31 & 15 \\
\hline White, L-1082 & 0.2 & 0.34 & 15 & 0.8 & 0.31 & 13 \\
\hline White, L-1057 & 0.4 & 0.34 & 12 & 0.7 & 0.38 & 14 \\
\hline White, AU-Alpha & 0.8 & 0.34 & 11 & 2.6 & 0.31 & 2 \\
\hline White, AU-Homer & 1.3 & 0.34 & 8 & 4.4 & 0.31 & 1 \\
\hline Contrast & MDiff & SE & AdjP & MDiff & SE & $\operatorname{AdjP}$ \\
\hline Local vs White & -0.3 & 0.37 & 0.9657 & -0.7 & 0.33 & 0.3751 \\
\hline Local vs Blue & -1.3 & 0.35 & 0.0554 & -0.5 & 0.31 & 0.5121 \\
\hline Local vs Yellow & -2.7 & 0.44 & 0.0136 & -1.4 & 0.61 & 0.2615 \\
\hline White vs Blue & -1.1 & 0.19 & 0.016 & 0.1 & 0.14 & 0.8888 \\
\hline White vs Yellow & -2.4 & 0.32 & 0.0079 & -0.8 & 0.55 & 0.6808 \\
\hline Blue vs Yellow & -1.3 & 0.29 & 0.0316 & -0.9 & 0.53 & 0.5208 \\
\hline AU-det vs AU-indt & -0.7 & 0.68 & 0.2979 & -2.8 & 0.65 & 0.0132 \\
\hline AU-indt vs Other-indt & 0.8 & 0.83 & 0.3755 & 3.0 & 0.62 & 0.0093 \\
\hline
\end{tabular}


Likawent Yeheyis and Wondimeneh Mekonnen

\begin{tabular}{|c|c|c|c|c|c|c|}
\hline \multirow[b]{3}{*}{ Species, Cultivar } & \multicolumn{6}{|c|}{ Mid Altitude } \\
\hline & \multicolumn{3}{|c|}{ Merawi } & \multicolumn{3}{|c|}{ Finote Selam } \\
\hline & Mean & SE & Rank & Mean & SE & Rank \\
\hline White, Local & 3.6 & 0.38 & 1 & 5.8 & 0.78 & 1 \\
\hline Blue, Bora & 0.5 & 0.13 & 16 & 0.8 & 0.1 & 11 \\
\hline Blue, Boregine & 1.3 & 0.13 & 11 & 0.8 & 0.1 & 12 \\
\hline Blue, Borlu & 1.6 & 0.13 & 6 & 0.7 & 0.1 & 13 \\
\hline Blue, Boruta & 1.2 & 0.13 & 13 & 0.9 & 0.1 & 7 \\
\hline Blue, Haags Blaue & 1.2 & 0.13 & 12 & 0.4 & 0.1 & 15 \\
\hline Blue, Probor & 0.9 & 0.13 & 14 & 0.4 & 0.1 & 16 \\
\hline Blue, Sanabor & 1.4 & 0.13 & 8 & 0.6 & 0.1 & 14 \\
\hline Blue, Vitabor & 1.4 & 0.13 & 9 & 0.8 & 0.1 & 10 \\
\hline Yellow, Bornal & 1.9 & 0.42 & 4 & 1.4 & 0.35 & 5 \\
\hline White, Feodora & 0.9 & 0.38 & 15 & 0.8 & 0.78 & 9 \\
\hline White, Fortuna & 1.3 & 0.38 & 10 & 0.9 & 0.78 & 8 \\
\hline White, L-1082 & 2.3 & 0.38 & 2 & 4.5 & 0.78 & 2 \\
\hline White, L-1057 & 1.7 & 0.38 & 5 & 1.3 & 0.78 & 6 \\
\hline White, AU-Alpha & 2 & 0.38 & 3 & 3 & 0.78 & 4 \\
\hline White, AU-Homer & 1.5 & 0.38 & 7 & 3.4 & 0.78 & 3 \\
\hline Contrast & MDiff & SE & AdjP & MDiff & SE & AdjP \\
\hline Local vs White & 2 & 0.41 & 0.0348 & 3.5 & 0.84 & 0.0513 \\
\hline Local vs Blue & 2.4 & 0.38 & 0.0189 & 5.1 & 0.78 & 0.0214 \\
\hline Local vs Yellow & 1.7 & 0.57 & 0.1205 & 4.5 & 0.86 & 0.0322 \\
\hline White vs Blue & 0.4 & 0.16 & 0.1988 & 1.6 & 0.32 & 0.0328 \\
\hline White vs Yellow & -0.3 & 0.45 & 0.9773 & 0.9 & 0.48 & 0.3635 \\
\hline Blue vs Yellow & -0.7 & 0.43 & 0.5337 & -0.7 & 0.36 & 0.375 \\
\hline AU-det vs AU-indt & 0.3 & 0.76 & 0.9494 & -0.3 & 1.56 & 0.9972 \\
\hline AU-indt vs Other-indt & 0.6 & 0.76 & 0.5412 & 2.3 & 1.56 & 0.1285 \\
\hline
\end{tabular}

\section{Seed yield}

The seed yield result from sweet white lupins at all locations in this study was lower than the other varieties evaluated together and the yield report from other studies. According to Natera et al. (1999) in their adaptation trial on white lupin as an alternative plant protein source in Mexico found a seed yield of $2.8 \mathrm{t} / \mathrm{ha}$. In addition, Heidel (2005) reported that the seed yield productivity of white lupin in Germany was $3.5 \mathrm{t} / \mathrm{ha}$. According to Mey (1999), sweet white lupin is adapted to cooler areas and cooler periods of the year. The high-altitude areas in Ethiopia are cooler than the mid-altitude areas. However, sweet white lupins didn't perform well (hit by anthracnose and root rot) at the high-altitude locations which could be associated with other factors like relatively higher rainfall during the whole 
growing season favored the disease incidence. According to Hill (2011), lupins are negatively affected by higher rainfall during the growing season if the amount of moisture is greater than the moisture deficit of the soil. In this study the average total annual rainfall from a ten-year data (2000-2009) at the high-altitude locations was $2348 \mathrm{~mm}$. In addition to this, Fusarium wilt could be the other factor for lower seed yield performance of sweet white lupins. Except at Finote Selam, the seed yield performance of yellow lupins was similar to the results by Heidel (2005) who reported a seed yield of $1.2 \mathrm{t} / \mathrm{ha}$ from yellow lupin. The relatively good seed yield performance of blue lupins at all locations compared to the other species with in location shows the wider adaptability of blue lupins in different growing environments. According to Spencer (2002), compared to white and yellow lupins, blue lupin could grow in different types of soils. In this study the seed yield obtained from most of the varieties evaluated at the mid altitude area was relatively lower than the high-altitude area. This shows that the productivity of lupin was relatively higher in the cool highland areas than in the mid-altitude areas of Ethiopia. According to a survey work done by the proponents of this study (Likawent Yeheyis et al., 2010) under traditional management system the average grain yield of local white lupin was 0.9 and $1.5 \mathrm{t} / \mathrm{ha}$ in the mid and high-altitude areas of Ethiopia, respectively.

Table 5. Least square means and contrast estimates for seed yield (t/ha) from an adaptation trial of seven white, eight blue, and one yellow annual lupin accessions at four locations (Merawi, Finoteselam, Kossober-1 and Kossober-2) in Ethiopia $(2009 / 10)$.

\begin{tabular}{|c|c|c|c|c|c|c|}
\hline \multirow[b]{3}{*}{$\begin{array}{l}\text { Species, } \\
\text { Cultivar }\end{array}$} & \multicolumn{6}{|c|}{ Mid Altitude } \\
\hline & \multicolumn{3}{|c|}{ Merawi } & \multicolumn{3}{|c|}{ Finote Selam } \\
\hline & Mean & SE & Rank & Mean & SE & Rank \\
\hline White, Local & 2.5 & 0.09 & 6 & 3.9 & 0.2 & 1 \\
\hline Blue, Bora & 2.8 & 0.2 & 4 & 2 & 0.38 & 7 \\
\hline Blue, Boregine & 3.3 & 0.2 & 2 & 2 & 0.38 & 6 \\
\hline Blue, Borlu & 3.3 & 0.2 & 1 & 2.6 & 0.38 & 2 \\
\hline Blue, Boruta & 1.8 & 0.2 & 10 & 2.4 & 0.38 & 3 \\
\hline $\begin{array}{l}\text { Blue, Haags } \\
\text { Blaue }\end{array}$ & 2.1 & 0.2 & 7 & 1.1 & 0.38 & 9 \\
\hline Blue, Probor & 2 & 0.2 & 8 & 1.3 & 0.38 & 8 \\
\hline Blue, Sanabor & 3.2 & 0.2 & 3 & 2.2 & 0.38 & 4 \\
\hline Blue, Vitabor & 2.7 & 0.2 & 5 & 2.1 & 0.38 & 5 \\
\hline Yellow, Bornal & 2 & 0.12 & 9 & 0.4 & 0.11 & 10 \\
\hline White, Feodora & 0 & 0.09 & 12 & 0.3 & 0.2 & 12 \\
\hline
\end{tabular}


White, Fortuna

White, L-1082

White, L-1057

White, AU-

Alpha

White,

Homer

Contrast

Local vs White

Local vs Blue

Local vs Yellow

White vs Blue

White vs

Yellow

Blue vs Yellow

AU-det vs AUindt

AU-indt vs

Other-indt

\begin{tabular}{rcc} 
MDiff & \multicolumn{1}{c}{ SE } & \multicolumn{1}{l}{ AdjP } \\
\hline 2.4 & 0.09 & 0.0008 \\
-0.2 & 0.11 & 0.4811 \\
0.5 & 0.14 & 0.0711 \\
-2.5 & 0.08 & 0.0005 \\
-1.8 & 0.12 & 0.0028 \\
0.7 & 0.13 & 0.0291 \\
0.4 & 0.16 & 0.0492
\end{tabular}

$0 \quad 0.16$

13

0.1

0.2

0.4

0.2

0.2

0.2

$\begin{array}{ll}0.1 & 0.2\end{array}$

\begin{tabular}{rrr} 
MDiff & \multicolumn{1}{c}{ SE } & \multicolumn{1}{c}{ AdjP } \\
\hline 3.8 & 0.22 & 0 \\
2 & 0.24 & 0.0008 \\
3.5 & 0.22 & 0 \\
-1.8 & 0.16 & 0.0004
\end{tabular}

$\begin{array}{lll}-0.3 & 0.13 & 0.2528\end{array}$

$\begin{array}{lll}1.5 & 0.17 \quad 0.0006\end{array}$

0.2

0.4

0.9335

$-0.2$

$0.4 \quad 0.9084$

High Altitude

\begin{tabular}{|c|c|c|c|c|c|c|}
\hline \multirow{2}{*}{$\begin{array}{l}\text { Species, } \\
\text { Cultivar }\end{array}$} & \multicolumn{3}{|c|}{ Kossober-1 } & \multicolumn{3}{|c|}{ Kossober-2 } \\
\hline & Mean & SE & Rank & Mean & SE & Rank \\
\hline White, Local & 0.9 & 0.25 & 10 & 3.1 & 0.33 & 8 \\
\hline Blue, Bora & 4.2 & 0.37 & 4 & 4.4 & 0.61 & 4 \\
\hline Blue, Boregine & 3.8 & 0.37 & 6 & 4.1 & 0.61 & 5 \\
\hline Blue, Borlu & 1.6 & 0.37 & 9 & 4 & 0.61 & 6 \\
\hline Blue, Boruta & 3.9 & 0.37 & 5 & 3.2 & 0.61 & 7 \\
\hline $\begin{array}{l}\text { Blue, Haags } \\
\text { Blaue }\end{array}$ & 2.2 & 0.37 & 7 & 2.1 & 0.61 & 9 \\
\hline Blue, Probor & 4.7 & 0.37 & 3 & 4.9 & 0.61 & 2 \\
\hline Blue, Sanabor & 4.8 & 0.37 & 2 & 4.7 & 0.61 & 3 \\
\hline Blue, Vitabor & 5.4 & 0.37 & 1 & 5 & 0.61 & 1 \\
\hline Yellow, Bornal & 1.8 & 0.39 & 8 & 1.9 & 0.39 & 10 \\
\hline White, Feodora & 0 & 0.44 & 13 & 0.2 & 0.33 & 16 \\
\hline White, Fortuna & 0 & 0.25 & 15 & 0.7 & 0.33 & 14 \\
\hline White, L-1082 & 0 & 0.25 & 14 & 0.8 & 0.33 & 13 \\
\hline White, L-1057 & 0 & 0.25 & 16 & 0.6 & 0.41 & 15 \\
\hline $\begin{array}{l}\text { White, } \\
\text { Alpha }\end{array}$ & 0.3 & 0.25 & 12 & 1.1 & 0.33 & 12 \\
\hline $\begin{array}{l}\text { White, } \quad \text { AU- } \\
\text { Homer }\end{array}$ & 0.4 & 0.25 & 11 & 1.5 & 0.33 & 11 \\
\hline
\end{tabular}




\begin{tabular}{|c|c|c|c|c|c|c|}
\hline Contrast & MDiff & SE & AdjP & MDiff & SE & AdjP \\
\hline Local vs White & 0.8 & 0.28 & 0.1254 & 2.3 & 0.36 & 0.015 \\
\hline Local vs Blue & -2.9 & 0.28 & 0.0044 & -0.9 & 0.39 & 0.2424 \\
\hline Local vs Yellow & -0.9 & 0.47 & 0.4222 & 1.2 & 0.51 & 0.2755 \\
\hline White vs Blue & -3.7 & 0.18 & 0.0009 & -3.2 & 0.26 & 0.0031 \\
\hline $\begin{array}{l}\text { White } \quad \text { vs } \\
\text { Yellow }\end{array}$ & -1.7 & 0.41 & 0.0476 & -1.1 & 0.42 & 0.1681 \\
\hline Blue vs Yellow & 2.0 & 0.41 & 0.03 & 2.1 & 0.45 & 0.035 \\
\hline $\begin{array}{l}\text { AU-det vs AU- } \\
\text { indt }\end{array}$ & -0.3 & 0.5 & 0.6724 & -0.6 & 0.7 & 0.5454 \\
\hline $\begin{array}{l}\text { AU-indt } \\
\text { Other-indt }\end{array}$ & 0.3 & 0.61 & 0.8226 & 0.8 & 0.66 & 0.1966 \\
\hline
\end{tabular}

\section{Alkaloid and amino acid profiles of lupin forage and seed}

Just as important as crude protein content in lupin seed is the alkaloid content because it limits the use of the crop as livestock feed and/or human food. The alkaloid content presented in this study might not be conclusive due to lack of replications. Nevertheless, the results show the difference in alkaloid content between bitter and sweet varieties and the variations within sweet varieties. The seed alkaloid content for the Local Landrace in this study was in agreement with the report by the proponents of this study (Likawent Yeheyis et al., 2011a) who reported an alkaloid content of 11,700 and $14,300 \mathrm{mg} / \mathrm{kg}$ DM from the Local Landrace seeds sampled from mid and high-altitude lupin growing areas, respectively. The seed alkaloid contents of most sweet entries in this study were in agreement with other studies outside Ethiopia (Bruno-Soares et al., 1999; Gdala et al., 1999). However, the maximum alkaloid content from sweet lupins in this study $(2292 \mathrm{mg} / \mathrm{kg} \mathrm{DM})$ was much higher than the maximum alkaloid content (720 $\mathrm{mg} / \mathrm{kg} \mathrm{DM}$ ) reported by the same authors. The overall mean seed alkaloid content $(2067 \mathrm{mg} / \mathrm{kg} \mathrm{DM})$ was higher at the mid-altitude than the high-altitude (1297 $\mathrm{mg} / \mathrm{kg} \mathrm{DM}$ ). A similar result was obtained with bitter lupins from the Rocky Mountain lupin (L. argenteus Pursh) in which alkaloid contents were negatively correlated with altitude (Carey and Wink, 1994). In addition, it could be associated with differences in the amount of rainfall in the two altitude areas. According to Christiansen et al. (1997), moisture stress during the vegetative phase increases seed alkaloid content in lupin. In general, the two sweet blue entries (Sanabor and Vitabor) had the lowest seed alkaloid content. 
The amount of the individual amino acids in both species in this study was in line with other similar studies (Campos-Andrada et al., 1999; Gilbert and Acamovic, 1999). In addition, the amount of the essential amino acids profile in this study fulfils the requirements of the ideal protein. According to Cole and Van Lunen (1994), the appropriate balance of essential amino acids in the ideal protein would be: lysine, 100; methionine + cysteine, 50; threonine, 65-67; tryptophan, 18; isoleucine, 50; leucine, 100; histidine, 33; phenylalanine + tyrosine, 100; and valine, 70. The relatively good balance of the essential amino acids is very important for the use of sweet lupin seeds as home-grown protein supplement feed in poultry production in Ethiopia.

\section{CONCLUSION}

Bitter white lupin is a traditional pulse crop in Ethiopia. However, the local landrace is unpalatable for livestock because of its high alkaloid content. In recent years, sweet blue lupines have been introduced and are being promoted as multipurpose crops. After a series of experiments, i.e., adaptation trials, laboratory evaluation, feeding and verification trials, the two sweet blue lupin varieties, Sanabor and Vitabor, were released and registered by the Ethiopian Ministry of Agriculture. The merits of the varieties are their low alkaloid content, high seed yield, resistance to anthracnose and fusarium, palatable for livestock and can be food for people. Thus, the varieties are recommended as multipurpose pulse crops for the traditional and new lupin growing areas in Ethiopia.

\section{Conflict of interest}

The authors declare no conflict of interest.

\section{Contribution of authors}

The first author (LY) conducted the field work, collected and analyzed the data, interpreted and prepared the manuscript. The second author (WM) also participated in the field work and data collection.

\section{REFERENCES}

Bhardwaj, H.L., Starner, D.E and van Santen, E. (2010). Preliminary evaluation of white lupin (Lupinus albus L.) as a forage crop in the Mid-Atlantic regions of the United States of America. Journal of Agricultural Science 2(4): 13-17.

Bruno-Soares, A.M., Campos-Andrada, M.P., Falcao, E and Cunha, L. (1999). An evaluation of the chemical composition and rumen degradability of a new Portuguese Lupinus luteus. In: Hill, G.D. 
(Ed.). Towards the $21^{\text {st }}$ century. Proceedings of the $8^{\text {th }}$ International Lupin Conference, Asilomar, California, USA, 11-16 May 1996, pp.115-119, Canterbury, New Zealand.

Campos-Andrada, M.P., Santana, F.M.C., Felgueiras, I., Mimoso, M.J and Empis, J.M.A. (1999). Nutritional value of Lupinus angustifolius and L. cosentinii accessions with diverse genetic origin. In: van Santen, E., Wink, M., Weissmann, S and Roemer, P. (Eds.). Lupin, an ancient crop for the new millennium. Proceedings of the $9^{\text {th }}$ International Lupin Conference, Klink/Muritz, 20-24 June, 1999, Pp.414-418, Canterbury, New Zealand, ISBN 0-86476-123-6.

Carey, D.B and Wink, M. (1994). Elevational variation of quinolizidine alkaloid contents in a lupin (Lupinus argenteus) of the Rocky Mountains. Journal of Chemical Ecology 20: 849-857.

Christiansen, J.L., Jornsgard, B., Buskov, S and Olsen, C.E. (1997). Effect of drought stress on content and composition of seed alkaloids in narrow-leafed lupin Lupinus angustifolius L. European Journal of Agronomy 7: 307-314.

Cole, D.J.A and Van Lunen, T.A. (1994). Ideal amino acid patterns. In: D’Mello, J.P.F. (Ed.). Amino acids in farm animal nutrition. Cab International, Wallingford, UK.

ECSA (Ethiopian Central Statistical Agency) (2017). Report on area and production of crops (Private peasant holdings, Meher season). Part I. ECSA, Addis Ababa, Ethiopia.

Fraser, M.D., Fychan, R and Jones, R. (2005). Comparative yield and chemical composition of two varieties of narrow-leafed lupin (Lupinus angustifolius) when harvested as whole-crop, moist grain and dry grain. Animal Feed Science and Technology 120: 43-50.

Gdala, J., Smulikowska, S., Zdunczyk, Z and Pastuszewska, B. (1999). Nutrients and anti-nutrients in three lupin species grown in Poland. In: van Santen, E., Wink, M., Weissmann, S and Roemer, P. (Eds.). Lupin, an ancient crop for the new millennium. Proceedings of the 9th International Lupin Conference, Klink/Muritz, 20-24 June, 1999. pp. 425-431, Canterbury, New Zealand, ISBN 086476-123-6.

Gilbert, C and Acamovic, T. (1999). The nutritional value of two British grown varieties of Lupinus albus for broiler chicken. In: van Santen, E., Wink, M., Weissmann, S and Roemer, P. (Eds.). Lupin, an ancient crop for the new millennium. Proceedings of the 9th International Lupin Conference, Klink/Muritz, 20-24 June, 1999. pp.400-402, Canterbury, New Zealand, ISBN 086476-123-6.

Heidel, W. (2005). Experiences with monitoring and control of anthracnose in lupin in the state of Mecklenburg-Western Pomerania, Germany. In: van Santen, E and Hill, G.D. (Eds.). Mexico, where old and new world lupins meet. Proceedings of the 11th International Lupin Conference, Guadalajara, Jalisco, Mexico. 4-9 May, 2005. pp. 124-127, Canterbury, New Zealand, ISBN 086476-165-1.

Hill, G. (2011). Too much water is not a good thing. In: Lupin Crops- an opportunity for today, a promise for the future. $13^{\text {th }}$ International Lupin Conference, Poznan, Poland. 6-10 June, 2011.

Kurlovich, B.S. (2002). Lupins: geography, classification, genetic resources and breeding. Intan Publishing House, St. Petersburg.

Likawent Yeheyis, Kijora, C., Solomon Melaku, Anteneh Girma and Peters, K.J. (2010). White lupin (Lupinus albus L.), the neglected multipurpose crop: Its production and utilization in the mixed crop-livestock farming system of Ethiopia. Livestock Research for Rural Development 22(74): $1-12$.

Likawent Yeheyis, Kijora, C., Wink, M and Peters, K.J. (2011). Effect of a Traditional Processing Method on Chemical Composition of Local White Lupin (Lupinus albus L.) Seed in NorthWestern Ethiopia. Zeitschrift für Naturforschung 66c: 403-408.

Likawent Yeheyis, Kijora, C., van Santen, E., Wink, M and Peters, K.J. (2012a). Crude protein, amino acid and alkaloid content of annual sweet lupin (Lupinus spp. L.) forages and seeds grown in Ethiopia. Experimental Agriculture 48 (3): 414-427.

Likawent Yeheyis, Kijora, C., van Santen, E and Peters, K.J. (2012b). Sweet annual lupins (Lupinus spp.): Their adaptability and productivity in different agro-ecological zones of Ethiopia. Journal of Animal Science Advances 2(2): 201-215. 
Likawent Yeheyis, Kijora, C., Firew Tegegne and Peters, K.J. (2012c). Sweet blue lupin (Lupinus angustifolius L.) seed as a substitute for concentrate mix supplement in the diets of yearling Washera rams fed on natural pasture hay as basal diet in Ethiopia. Tropical Animal Health and Production 44: 1255-1261.

Mey, van Der J.A.M. (1999). Matching sweet white lupin (Lupinus albus) cultivar groups and environments in the summer rainfall areas of Southern Africa. In: Santen, E.V., Wink, M., Weissmann, S and Roemer, P. (Eds.). Lupin, an ancient crop for the new millennium. Proceedings of the 9th International Lupin Conference, Klink/Muritz, 20-24 June, 1999. Canterbury, New Zealand, ISBN 0-86476-123-6.

Mihailovic, V., Hill, G.D., Mikic, A., Cupina, B and Vasiljevic, S. (2008). White lupin as a forage crop on alkaline soils. In: Palta, J.A and Berger, J.B. (eds). Lupins for health and wealth. Proceedings of the 12th International Lupin Conference, 14-18 Sept. 2008, Fremantle, Western Australia. Canterbury, New Zealand. ISBN 0-86476-153-8.

Muyekho, F.N. (1999). A review on evaluation and agronomy of promising lupin varieties in Kenya. Farmers, their animals and the environment. ILRI on disc, FAO/ILRI production.

Natera, F.Z., Lopez, P.G., Moreno, J.R and Ruiz, M.A. (1999). Agricultural experiments with Lupinus albus in Mexico. In: van Santen, E., Wink, M., Weissmann, S and Roemer, P. (Eds.). Lupin, an ancient crop for the new millennium. Proceedings of the 9th International Lupin Conference, Klink/Muritz, 20-24 June, 1999. pp.203-204, Canterbury, New Zealand, ISBN 0-86476-123-6.

Naumann, C and Bassler, R. (1997). Die chemiche untersuchung von futtermitteln. methodenbuch, Band III (The chemical analysis of feeds. Book of Methods Vol. 3.). Ergänzungen, 1993, VDLUFA, Verlag. Darmstadt, Germany.

Spencer, C. (2002). Lupins. Technical report on lupin production. Springdale Crop Synergies Ltd. East Yorkshire, UK. http://www.ienica.net/crops/lupins.pdf

Takunov, I.P and Yagovenko, L.L. (1999). Yellow lupin (Lupinus luteus L.) as a green manure crop preceding winter rye (Secale cereale L.). In: van Santen, E., Wink, M., Weissmann, S and Roemer, P. (Eds.). Lupin, an ancient crop for the new millennium. Proceedings of the 9th International Lupin Conference, Klink/Muritz, 20-24 June, 1999. pp.199-200, Canterbury, New Zealand, ISBN 0-86476-123-6.

Wink, M., Meißner, C and Witte, L. (1995). Patterns of quinolizidine alkaloids in 56 species of the genus Lupinus. Phytochemistry 38: 139-153. 